\title{
In vitro Antihyperglycemic and Chelating Potential of Selected Ayurvedic Medicinal Plants
}

\begin{abstract}
A. Y. COULIBALY ${ }^{1 *}$, R. HASHIM ${ }^{2}$, P. A. E. D. SOMBIÉ ${ }^{1,4}$, S. F. SULAIMAN ${ }^{3}$, O. SULAIMAN ${ }^{2}$, L. Z. P. ANG ${ }^{2}$, K. L. OOI $^{3}$ AND M. KIENDREBEOGO ${ }^{1}$

Unit of formation and Research in Sciences and Technology, University Norbert Zongo, Koudougou, ${ }^{1}$ Laboratory of Applied Biochemistry and Chemistry (LABIOCA), UFR/SVT, University Ouaga 1 Pr Joseph Ki-Zerbo, 09 BP 848 Ouagadougou 09, Burkina Faso, ${ }^{2}$ Division of Bioresource, Paper and Coatings Technology, School of Industrial Technology, ${ }^{3}$ School of Biological Sciences, Universiti Sains Malaysia, Penang, Malaysia, ${ }^{4}$ National Center of Scientific Research and Technology, Institute of Environment and Agricultural Research, Crop Production Department, 01 P.O. Box 476 Ouagadougou, Burkina Faso
\end{abstract}

\section{Coulibaly et al.: Antihyperglycemic and chelating potential of Ayurvedic plants}

\begin{abstract}
Seven medicinal plants used in folk medicine to relieve various diseases including diabetes, were investigated for antihyperglycemic activities. Two types of extracts for each plant were processed by decoction and by soaking in an aqueous-acetone mixture. The inhibitory activities were tested on $\alpha$-amylase and $\alpha$-glucosidase along with chelating activity. The aqueous-acetone extracts of Feretia apodanthera and Ozoroa insignis exerted strong inhibition on $\alpha$-glucosidase $(96.51 \pm 0.14$ and $96.44 \pm 0.68 \%$, respectively) but lower inhibition on $\alpha$-amylase $(21.60 \pm 1.69$ and $93.85 \pm 6.58 \%$, respectively) and displayed a weak chelating activity as compared to the respective standards acarbose and ethylenediaminetetraacetic acid. Subsequent column fractionation resulted in selectively strong inhibition of $\alpha$-glucosidase. The inhibitory activities of $\alpha$-amylase and $\alpha$-glucosidase were weakly correlated $(R=0.389)$ and both were inversely correlated with metal chelating activity $(R=-0.731$ and $R=-0.809$, respectively). Volatile compounds, 1-nonadecene and 1-heptadecene identified by Gas chromatography-mass spectrometry were related to the inhibitory activities of $\alpha$-amylase and $\alpha$-glucosidase enzymes. This potent inhibition of sugar degrading enzymes may help to manage the hyperglycaemia occurring in type 2 diabetes.
\end{abstract}

Key words: $\alpha$-amylase, $\alpha$-glucosidase, diabetes, chelating activity, GC-MS, medicinal plants, column fractionation

Glucose is the main carbohydrate that the body breaks down for energy. This energy is needed for body processes such as breathing, body temperature, contraction and relaxation of the heart and muscles, brain, cells, nerves and blood cells. Glucose homeostasis is of central importance in metabolism and is heavily regulated. Several studies demonstrated that chronic exposure to high circulating glucose increases reactive oxygen species (ROS) production, decreases insulin content and glucose-stimulated insulin secretion of $\beta$-cells ${ }^{[1]}$ and promote insulin resistance ${ }^{[2]}$.

Glucose, and many of its metabolites, can react with hydrogen peroxide in the presence of transition metals, such as $\mathrm{Fe}^{2+}$ and $\mathrm{Cu}^{2+}$, to form the most reactive $\mathrm{ROS}$ hydroxyl radical ${ }^{[3,4]}$. Glucose uptake increases during physical activities and the plasma glucose level does not normally exceed $1.6 \mathrm{~g} / \mathrm{l}$ in the body. This normoglycemia is maintained through an intricate regulatory and counterregulatory neuro-hormonal

*Address for correspondence

E-mail: coulahmede@yahoo.fr

May-June 2020 system including insulin and glucagon ${ }^{[5]}$. An increment in plasma glucose will stimulate insulin release and suppress glucagon secretion to prevent further increments and restore normoglycemia. Inversely, a decrement in plasma glucose will suppress the release of insulin, decrease glucose uptake and trigger the release of counter-regulatory hormones (glucagon, catecholamines, cortisol and growth hormone). This normoglycemia regulation also includes hexokinase and glucokinase involve in the phosphorylation of glucose in the tissues ${ }^{[5]}$. Therefore, in pathological situation, the normoglycemia is not maintained and glucose homeostasis is disturbed. Diabetes mellitus

This is an open access article distributed under the terms of the Creative Commons Attribution-NonCommercial-ShareAlike 3.0 License, which allows others to remix, tweak, and build upon the work non-commercially, as long as the author is credited and the new creations are licensed under the identical terms 
is a metabolic disorder characterized by chronic hyperglycemia with disturbances in carbohydrate, fat and protein metabolism. It results from absolute or relative lack of insulin secretion that defines two major types of diabetes mellitus. The type 1 (insulindependent), which is caused by $\beta$-cell destruction in pancreatic islets and type 2 (non-insulin dependent) due to abnormalities in glucoreceptor of $\beta$-cells, reduced sensitivity of peripheral tissues to insulin, excess of hyperglycemic hormones like glucagon ${ }^{[6]}$. Type 2 diabetes is one of the primary threats to human health due to increasing prevalence, chronic course and disabling complications ${ }^{[7]}$. Diverse therapeutic strategies have been proposed including stimulation of endogenous insulin secretion, enhancement of the action of insulin at the target tissues, oral hypoglycaemic agents (biguanides and sulfonylureas) and the inhibition of degradation of dietary starch by glycosidases such as $\alpha$-amylase and $\alpha$-glucosidase ${ }^{[8]}$. $\alpha$-Amylase catalyses the initial step in hydrolysis of starch and long chain carbohydrates to oligosaccharides (maltose, maltotriose, oligoglucans) which are further proceed by $\alpha$-glucosidase and degraded to glucose that will further enter the blood-stream and slowly accumulated in the plasma resulting to a post-prandial hyperglycaemia. Then, the inhibition of pancreatic $\alpha$-amylase and $\alpha$-glucosidase delay carbohydrate digestion, reduce glucose absorption and post-prandial serum glucose levels ${ }^{[9]}$. Some glycosidase inhibitors such as acarbose and miglitol are currently available for clinical use but they are not so accurate and well-tolerated by everybody because of some serious side effects ${ }^{[10]}$.

Natural products, especially medicinal plants are getting more importance in the treatment of diabetes as they are free from side effects and cheaper ${ }^{[11]}$. Many herbal extracts have been reported to possess antidiabetic activities and are currently being used in Ayurveda for the treatment of diabetes. Seven medicinal plants were targeted in this study. The antidiabetic activity of Scoparia dulcis ${ }^{[12]}$ and Euphorbia balsamifera ${ }^{[13]}$ were reported but no information was recorded about the antidiabetic potential of Feretia apodanthera, Lepidagathis anobrya, Fadogia agrestis, Sporobolus pyramidalis and Ozoroa insignis. Then the present work aims to evaluate the in vitro antihyperglycemic potential of these plants.

\section{MATERIALS AND METHODS}

Aerial parts (stem and leaves) of seven herbaceous plants species Euphorbia balsamifera Ait. (Euphorbiaceae), Feretia apodanthera Del. (Rubiaceae), Lepidagathis anobrya Nees (Acanthaceae), Fadogia agrestis Schweinf. ex Hiern. (Rubiaceae), Sporobolus pyramidalis P. Beauv. (Poaceae), Scoparia dulcis L. (Scrophulariaceae) and Ozoroa insignis Del. (Anacardiaceae) were freshly collected at Gampela ( $25 \mathrm{~km}$ east of Ouagadougou, Burkina Faso) on June 2013 with the agreement of the local agent of the government of Burkina Faso. Taxonomic identification was carried out at the Laboratoire de Biologie et Ecologie Vegetales, University of Ouagadougou, Burkina Faso and a voucher specimen was deposited for each plant under the following numbers, Euphorbia balsamifera (EB_aca 001), Feretia apodanthera (FA_rca 001), Lepidagathis anobrya (LA_nca 001), Fadogia agrestis (FA_sca 001), Sporobolus pyramidalis (SP_pca 001), Scoparia dulcis (SD_ca 002) and Ozoroa insignis (OI_dca 001). The plants were air-dried away from the sun inside the laboratory and then reduced into powder for future use.

All chemicals used in this study were of analytical grade. Acetone, methanol and hexane were purchased from Fisher, hydrochloric acid from QRëC. Sodium phosphate, sodium chloride, ferrozine, ferrous chloride hexahydrate, $\alpha$-glucosidase (from Saccharomyces cerevisiae), $\alpha$-amylase (from Bacillus licheniformis), iodine, p-nitrophenyl- $\alpha$-D-glycopyranoside and acarbose were purchased from Sigma-Aldrich (USA), anhydrous sodium carbonate from Fluka (Switzerland), Starch from Wako (Japan), and potassium iodide from Univar Ajax Chemicals.

\section{Extraction:}

An amount of $25 \mathrm{~g}$ of powder from each plant was added to $250 \mathrm{ml}$ of distilled water and the mixture was boiled for $45 \mathrm{~min}$ on a Soxhlet apparatus to make a decoction that was air-dried at $50^{\circ}$ to give the water extract. Another $25 \mathrm{~g}$ of powder from each plant was soaked in $250 \mathrm{ml}$ of a mixture of acetone/water $(70 / 30 \mathrm{v} / \mathrm{v})$ for $48 \mathrm{~h}$ and after filtration, the solvent was evaporated under reduced pressure $\left(132 \mathrm{hPa}, 40^{\circ}\right)$ and then airdried at $50^{\circ}$ to give a dried extract (aqueous-acetone extract). Then, both the extraction processes were repeated 3 times.

\section{Fractionation:}

The most bioactive aqueous-acetone extracts of Feretia apodanthera and Ozoroa insignis were chromatographed on a silica gel column (60 -120 mesh) and successively eluted with increasing polarity gradients of a mixture $(60 \mathrm{ml})$ of hexane/ acetone/water $\quad(5: 2: 0.2, \quad 5: 3: 0.2, \quad 5: 4: 0.2, \quad 5: 5: 0.2$, 
5:6:0.2, 5:6:0.4, 5:6:0.6, 5:6:0.8, 5:6:1, 5:6:1.2 v/v/v) and then isocratic elution with acetone/water $(7: 3 \mathrm{v} / \mathrm{v})$. Thirty-seven and thirty-three initial fractions $(20 \pm 2 \mathrm{ml}$ for each fraction) were collected from $F$. apodanthera and $O$. insignis, respectively. Then, each collected fraction was developed on a silica gel GF254 thin layer chromatography plate with an eluent composed of a mixture of hexane/acetone/water $(5: 6: 0.4 \mathrm{v} / \mathrm{v} / \mathrm{v})$ and identified by UV light at 254 and $365 \mathrm{~nm}$. After merger of fractions with same chromatographic profiles, 9 fractions were finally obtained from $F$. apodanthera (F1 to F9) and 10 fractions from $O$. insignis (O1 to $\mathrm{O} 10)$.

\section{Metal chelating activity:}

Chelating power of the plant samples was determined as previously described by Ooi et al. ${ }^{[14]}$ with some modifications. The sample solution $(50 \mu \mathrm{l}, 1 \mathrm{mg} / \mathrm{ml}$ for extracts and $50 \mu \mathrm{g} / \mathrm{ml}$ for fractions) was mixed with ferrous chloride hexahydrate $(10 \mu 1,2.0 \mathrm{mM}$ in distilled water) and distilled water $(130 \mu \mathrm{l})$. After 5 min of incubation, the reaction was initiated by the addition of ferrozine ( $20 \mu \mathrm{l}, 5 \mathrm{mM}$ in distilled water). After $10 \mathrm{~min}$ of incubation at room temperature $\left(25^{\circ}\right)$ in darkness, the absorbance was measured at $562 \mathrm{~nm}$ using a Multiskan EX microplate reader (Thermo Fisher Scientific, Finland). The chelating activity (\%) was calculated according to the following Eqn., \% chelating activity $=$ (absorbance of negative control-absorbance of extract $)) /($ absorbance of negative control $) \times 100$.

\section{a-Amylase inhibitory assay:}

The $\alpha$-amylase inhibitory activity of the plant samples was screened based on the starch-iodine method as described by Sudha et al. ${ }^{[8]}$ with some modifications. The assay mixture was composed of $10 \mu \mathrm{l}$ of sodium phosphate buffer $(0.02 \mathrm{M}, \mathrm{pH} 6.9$ containing $6 \mathrm{mM}$ sodium chloride), $50 \mu 1$ of $\alpha$-amylase enzyme solution (40 U/ml in distilled water) and $50 \mu \mathrm{l}$ of sample solution $(1 \mathrm{mg} / \mathrm{ml}$ in buffer). After incubation (10 $\mathrm{min}$, $\left.37^{\circ}\right)$, soluble starch ( $40 \mu 1,1 \%$ in buffer) was added as substrate to start the enzymatic reaction and again incubated at $37^{\circ}$ for $15 \mathrm{~min}$. Then $\mathrm{HCl}(40 \mu 1,1 \mathrm{M})$ was added to stop the enzymatic reaction, followed by the addition of $10 \mu \mathrm{l}$ of iodine reagent $(5 \mathrm{mM}$ iodine and $5 \mathrm{mM}$ potassium iodide). The colour change was noted and the absorbance was read at $620 \mathrm{~nm}$ on a Multiskan EX microplate reader (Thermo Fisher Scientific, Finland). A negative control without plant sample was run to unsure enzyme activity (yellow colour) together with a positive control without $\alpha$-amylase (blue colour). For each assay, a blank without iodine was simultaneously run for background subtraction. Acarbose was used as standard inhibitor. Percent inhibition was calculated as follows, $\% \alpha$-amylase inhibition $=$ (absorbance of sample-absorbance of negative control)/(absorbance of positive control-absorbance of negative control) $\times 100$.

A dark-blue colour indicates the presence of starch; yellow colour indicates the absence of starch while a brownish colour indicates partially degraded starch in the reaction mixture. In the presence of inhibitors from the extracts, the starch added to the enzyme assay mixture is not degraded and gives a dark-blue colour complex whereas no colour complex is developed in the absence of the inhibitor, indicating that starch is completely hydrolysed by $\alpha$-amylase.

\section{$\alpha$-Glucosidase inhibitory assay:}

The $\alpha$-glucosidase inhibitory activity was determined according to the method of Ooi et al. ${ }^{[14]}$ with slight modifications. The sample solution as inhibitor (25 $\mu \mathrm{l} ; 0.25,0.5$ and $1 \mathrm{mg} / \mathrm{ml}$ ) was mixed with sodium phosphate buffer $(75 \mu 1,0.1 \mathrm{M}, \mathrm{pH} 7)$ and $\alpha$-glucosidase enzyme solution $(25 \mu \mathrm{l}, 5 \mathrm{U} / \mathrm{ml})$. After incubation $\left(5 \mathrm{~min}, 37^{\circ}\right.$ ) the enzymatic reaction was started by the addition of the substrate (PNPG) p-nitro-phenyl- $\alpha$-Dglycopyranoside $(25 \mu 1,15 \mathrm{mM})$. Then, the reaction was run for $40 \mathrm{~min}$ at $37^{\circ}$ and sodium carbonate solution $(100 \mu 1,0.2 \mathrm{M})$ was added to terminate the reaction. Acarbose was used as a positive control and a negative control without sample solution was simultaneously run. A blank without the substrate PNPG was also run for each assay. The increase in absorbance due to hydrolysis of the substrate PNPG by $\alpha$-glucosidase was measured at $405 \mathrm{~nm}$ using a Multiskan EX microplate reader (Thermo Fisher Scientific, Finland). Each assay was run in triplicate. Percent inhibition was calculated as follows, $\% \alpha$-glucosidase inhibition $=($ absorbance of negative control-absorbance of extract)/(absorbance of negative control) $\times 100$.

\section{Gas chromatography-mass spectrometer analysis:}

A Shimadzu-GC-9A gas chromatograph, FID at 220, $\mathrm{N} 2$ at $1.0 \mathrm{ml} / \mathrm{min}$, SPB-5 capillary column (30 $\mathrm{m} \times 0.53 \mathrm{~mm}$ ID; $0.3 \mu \mathrm{mdf})$, split ratio 1:30 injector temperature $240^{\circ}$, column temperature maintained at $50^{\circ}$ for the first $5 \mathrm{~min}$ and then raised to $235^{\circ}\left(5^{\circ} / \mathrm{min}\right)$ followed by $5 \mathrm{~min}$ at $235^{\circ}$. GC-MS: Hewlett-Packard 5890 gas chromatograph, combined with a Jeol JMSHX 110 mass spectrometer with source at $270^{\circ}$ at $70 \mathrm{eV}$. Injector was set at $270^{\circ}$ with splitting ratio 1:30. The analysis was performed on the aforementioned program on equivalent column HP-5 (25 $\mathrm{m} \times 0.22 \mathrm{~mm}$ 
and $0.25 \mu \mathrm{mdf}$ ). A mass spectral survey was performed using the NIST mass spectral search program 2008 with similarity indices more than $90 \%$.

\section{Statistical analysis:}

All the tests were run in triplicate and data are presented as mean \pm standard deviation. Data were analysed by one-way analysis of variance followed by the Tukey multiple-comparison test with XLSTAT 2013.4.08. A p-value less than 0.05 was used as the criterion for statistical significance.

\section{RESULTS AND DISCUSSION}

The antihyperglycemic activity of the different plant samples was assayed in vitro by the inhibition of $\alpha$-amylase and $\alpha$-glucosidase. The water-extract and the aqueous-acetone extract of plant samples exhibited different antihyperglycemic activity (Table 1). Only the aqueous-acetone extract of $F$. apodanthera and $O$. insignis showed significant inhibition of $\alpha$-amylase (21.60 \pm 1.69 and $93.85 \pm 6.58 \%$, respectively), while the other extracts exhibited weak activity $(2.67 \pm 0.35$, $3.91 \pm 0.28$ and $3.93 \pm 0.75 \%)$ or no activity $(<1 \%)$.

The inhibition of $\alpha$-glucosidase was assayed at different concentrations (Table 1). Significant inhibitory activity was exhibited at the $100 \mu \mathrm{g} / \mathrm{ml}$ by both water-extract and aqueous-acetone extract of $F$. apodanthera and $O$. insignis $(\geq 87.70 \pm 0.85 \%)$ as well as the extracts of F. agrestis $(90.81 \pm 0.69$ and $96.45 \pm 0.54 \%)$ and E. balsamifera $(52.67 \pm 0.37 \%)$, while L. anobrya, $S$. dulcis and $S$. pyramidalis had no activity $(<1 \%)$. The activities of $F$. agrestis and the water-extract of $F$. apodanthera were dose-dependent while those of the aqueous-acetone extracts of $F$. apodanthera and both extracts of $O$. insignis did not decrease even at lower concentrations of 25 and $50 \mu \mathrm{g} / \mathrm{ml}$. All extracts exhibited moderate metal chelating power $(28.22 \pm 1.17$ to $49.01 \pm 2.48 \%$ ) except the aqueous-acetone extracts of $F$. apodanthera and $O$. insignis that did not show any activity.

Subsequent fractionation of the aqueous-acetone extracts of $F$. apodanthera and $O$. insignis was screened for chelating power and antihyperglycemic activity (Table 2). All the fractions showed weak chelating activity ( $7.39 \pm 0.67$ to $23.33 \pm 2.90 \%$ ) and also weak inhibition of $\alpha$-amylase activity except the F2, O2 and O7 fractions with moderate inhibition $(33.15 \pm 3.18$, $30.30 \pm 077$ and $36.69 \pm 2.45 \%$, respectively) and the F1 and $\mathrm{O} 2$ fractions with higher inhibitions (57.24 \pm 0.99 and $54.15 \pm 0.76 \%$, respectively). At the highest dose of $100 \mu \mathrm{g} / \mathrm{ml}$ tested, most fractions exhibited strong

TABLE 1: INHIBITION OF $\alpha$-GLUCOSIDASE AND $\alpha$-AMYLASE BY CRUDE AQUEOUS-ACETONE AND WATER EXTRACTS

\begin{tabular}{|c|c|c|c|c|c|c|c|}
\hline \multirow{2}{*}{ Plant } & \multirow{2}{*}{ Extracts } & \multirow{2}{*}{ Yield (\%) } & \multirow{2}{*}{$\begin{array}{l}\text { Metal chelating } \\
\text { (\%) }\end{array}$} & \multirow{2}{*}{$\begin{array}{c}\text { a-Amylase } \\
\text { inhibition (\%) }\end{array}$} & \multicolumn{3}{|c|}{ a-Glucosidase inhibition (\%) } \\
\hline & & & & & 25 & 50 & 100 \\
\hline \multirow[b]{2}{*}{ E. bal } & Water & $22.04 \pm 0.62^{c}$ & $44.30 \pm 1.23^{c}$ & $3.93 \pm 0.75^{a}$ & - & - & $N A^{a}$ \\
\hline & $\begin{array}{l}\text { aqueous- } \\
\text { acetone }\end{array}$ & $34.9 \pm 8.57^{d}$ & $34.03 \pm 2.97^{\mathrm{bc}}$ & $N A^{a}$ & - & - & $52.67 \pm 0.37^{b}$ \\
\hline \multirow[b]{2}{*}{ F. agres } & Water & $17.2 \pm 4.58^{\mathrm{b}}$ & $35.24 \pm 3.99^{\mathrm{bc}}$ & $N A^{a}$ & $N A^{a}$ & $12.92 \pm 0.94^{\mathrm{a}}$ & $90.81 \pm 0.69^{c}$ \\
\hline & $\begin{array}{l}\text { aqueous- } \\
\text { acetone }\end{array}$ & $13.86 \pm 1.10^{\mathrm{ab}}$ & $28.68 \pm 1.00^{\mathrm{bc}}$ & $N A^{a}$ & $72.13 \pm 4.25^{c}$ & $81.96 \pm 0.84^{\mathrm{b}}$ & $96.45 \pm 0.54^{c}$ \\
\hline \multirow[b]{2}{*}{ F. apod } & Water & $16.44 \pm 4.41^{\mathrm{b}}$ & $30.80 \pm 1.88^{\mathrm{bc}}$ & $3.91 \pm 0.28^{a}$ & $25.28 \pm 1.76^{\mathrm{b}}$ & $62.39 \pm 2.51^{\mathrm{ab}}$ & $87.70 \pm 0.85^{c}$ \\
\hline & $\begin{array}{l}\text { aqueous- } \\
\text { acetone }\end{array}$ & $28.06 \pm 4.04^{\text {cd }}$ & $N A^{a}$ & $21.60 \pm 1.69^{b}$ & $96.51 \pm 0.14^{d}$ & $96.70 \pm 0.27^{\mathrm{b}}$ & $98.01 \pm 0.49^{c}$ \\
\hline \multirow[b]{2}{*}{ L. anob } & Water & $10.54 \pm 1.89^{a}$ & $47.26 \pm 0.54^{c}$ & $N A^{a}$ & - & - & $N A^{a}$ \\
\hline & $\begin{array}{l}\text { aqueous- } \\
\text { acetone }\end{array}$ & $13.56 \pm 4.69^{\mathrm{ab}}$ & $42.26 \pm 1.90^{c}$ & $N A^{a}$ & - & - & $N A^{a}$ \\
\hline \multirow[b]{2}{*}{ O. insig } & Water & $13.48 \pm 1.01^{\mathrm{ab}}$ & $28.22 \pm 1.17^{\mathrm{bc}}$ & $N A^{a}$ & $92.14 \pm 1.01^{\mathrm{d}}$ & $94.35 \pm 0.51^{\mathrm{b}}$ & $99.40 \pm 0.46^{c}$ \\
\hline & $\begin{array}{l}\text { aqueous- } \\
\text { acetone }\end{array}$ & $18.58 \pm 5.28^{b}$ & $N A^{a}$ & $93.85 \pm 6.58^{c}$ & $96.44 \pm 0.68^{d}$ & $98.78 \pm 0.73^{b}$ & $97.23 \pm 0.50^{c}$ \\
\hline \multirow[b]{2}{*}{ S. dulcis } & Water & $12.06 \pm 0.59^{a}$ & $49.01 \pm 2.48^{c}$ & $2.67 \pm 0.35^{\mathrm{a}}$ & - & - & $\mathrm{NA}^{\mathrm{a}}$ \\
\hline & $\begin{array}{l}\text { aqueous- } \\
\text { acetone }\end{array}$ & $12.36 \pm 2.77^{a}$ & $48.28 \pm 0.11^{c}$ & $N A^{a}$ & - & - & $N A^{a}$ \\
\hline \multirow[b]{2}{*}{ S. $p y r$} & Water & $14.36 \pm 2.48^{\mathrm{ab}}$ & $47.53 \pm 1.78^{c}$ & $\mathrm{NA}^{\mathrm{a}}$ & - & - & $\mathrm{NA}^{\mathrm{a}}$ \\
\hline & $\begin{array}{l}\text { aqueous- } \\
\text { acetone }\end{array}$ & $10.24 \pm 0.39^{a}$ & $47.81 \pm 2.47^{c}$ & $N A^{a}$ & - & - & $N A^{a}$ \\
\hline
\end{tabular}

The final concentrations tested were $100 \mu \mathrm{g} / \mathrm{ml}$ for chelating activity, $100 \mu \mathrm{g} / \mathrm{ml}$ for a-amylase inhibition and 25,50 and $100 \mu \mathrm{g} / \mathrm{ml}$ for a-glucosidase inhibition. Values with superscript letters, a, b, c, d, e differ significantly $(p<0.05)$. NA is no activity $(\leq 1 \%)$, - not tested. E. bal, Euphorbia balsamifera; F. agres, Fadogia agrestis; F. apod, Feretia apodanthera; L. anob, Lepidagathis anobrya; 0 . insig, O. insignis and S. pyr, Sporobolus pyramidalis 
TABLE 2: INHIBITION OF A-GLUCOSIDASE AND A-AMYLASE BY FRACTIONS FROM F. APODANTHERA AND O. INSIGNIS

\begin{tabular}{|c|c|c|c|c|c|c|}
\hline \multirow{2}{*}{ Fractions } & \multirow{2}{*}{ Yield (\%) } & \multirow{2}{*}{ Metal chelating (\%) } & \multirow{2}{*}{$\begin{array}{c}\text { a-amylase } \\
\text { inhibition (\%) }\end{array}$} & \multicolumn{3}{|c|}{ a-glucosidase inhibition (\%) } \\
\hline & & & & 25 & 50 & 100 \\
\hline F1 & $1.46^{c}$ & $14.14 \pm 1.90^{a}$ & $57.24 \pm 0.99^{c}$ & - & - & $N A^{a}$ \\
\hline $\mathrm{F} 2$ & $0.38^{b}$ & $11.81 \pm 1.18^{a}$ & $33.15 \pm 3.18^{\mathrm{bc}}$ & - & - & $N A^{a}$ \\
\hline F3 & $1.58^{c}$ & $23.33 \pm 2.90^{\mathrm{a}}$ & $13.49 \pm 2.30^{\mathrm{b}}$ & - & - & $N A^{a}$ \\
\hline F4 & $2.02^{c}$ & $12.88 \pm 1.72^{\mathrm{a}}$ & $6.87 \pm 0.71^{b}$ & $94.05 \pm 1.03^{c}$ & $95.15 \pm 0.67^{c}$ & $99.80 \pm 0.33^{c}$ \\
\hline F5 & $23.02^{d}$ & $9.75 \pm 0.75^{a}$ & $6.02 \pm 3.77^{b}$ & $96.42 \pm 0.28^{c}$ & $95.55 \pm 0.34^{c}$ & $99.63 \pm 0.26^{c}$ \\
\hline F6 & $0.43^{b}$ & $12.46 \pm 1.57^{a}$ & $13.56 \pm 1.27^{\mathrm{b}}$ & - & - & $N A^{a}$ \\
\hline F7 & $39.65^{\mathrm{e}}$ & $10.82 \pm 0.45^{a}$ & $3.90 \pm 0.22^{\mathrm{a}}$ & $96.03 \pm 0.51^{c}$ & $95.74 \pm 0.54^{c}$ & $99.34 \pm 0.69^{c}$ \\
\hline F8 & $17.67^{d}$ & $17.47 \pm 1.97^{a}$ & $N A^{a}$ & $93.03 \pm 0.28^{c}$ & $93.82 \pm 0.78^{c}$ & $99.33 \pm 0.45^{c}$ \\
\hline F9 & $5.48^{c}$ & $18.26 \pm 1.35^{a}$ & $N A^{a}$ & $68.25 \pm 0.34 b^{b c}$ & $71.87 \pm 0.55^{\mathrm{bc}}$ & $97.35 \pm 0.47^{c}$ \\
\hline 01 & $5.71^{c}$ & $11.72 \pm 0.85^{a}$ & $30.30 \pm 077^{b c}$ & - & - & $N A^{a}$ \\
\hline $\mathrm{O} 2$ & $0.11^{b}$ & - & $54.15 \pm 0.76^{c}$ & - & - & - \\
\hline 03 & $0.61^{b}$ & $10.51 \pm 1.81^{\mathrm{a}}$ & $17.45 \pm 1.92^{\mathrm{b}}$ & - & - & $N A^{a}$ \\
\hline 04 & $0.32^{b}$ & $17.62 \pm 1.88^{a}$ & $18.71 \pm 1.52^{b}$ & - & - & $21.36 \pm 3.03^{b}$ \\
\hline 05 & $0.65^{b}$ & $10.90 \pm 1.40^{\mathrm{a}}$ & $14.87 \pm 1.85^{b}$ & $N A^{a}$ & $86.39 \pm 1.51^{c}$ & $98.06 \pm 0.72^{c}$ \\
\hline 06 & $0.54^{\mathrm{b}}$ & $14.55 \pm 1.49^{a}$ & $18.52 \pm 2.4^{b}$ & $N A^{a}$ & $N A^{a}$ & $94.86 \pm 2.34^{c}$ \\
\hline 07 & $43.87^{e}$ & $7.39 \pm 0.67^{a}$ & $36.69 \pm 2.45^{\mathrm{bc}}$ & $97.74 \pm 0.41^{c}$ & $98.50 \pm 0.38^{c}$ & $99.57 \pm 0.48^{c}$ \\
\hline 08 & $0.08^{a}$ & $14.62 \pm 1.43^{a}$ & $N A^{a}$ & - & - & $N A^{a}$ \\
\hline 09 & $17.65^{d}$ & $8.02 \pm 0.57^{a}$ & $N A^{a}$ & $84.41 \pm 0.11^{c}$ & $89.04 \pm 0.17 c$ & $99.47 \pm 0.33^{c}$ \\
\hline 010 & $4.00^{c}$ & $7.62 \pm 0.42^{\mathrm{a}}$ & $N A^{a}$ & $48.66 \pm 0.79^{b}$ & $63.06 \pm 2.93^{b c}$ & $98.30 \pm 0.60^{c}$ \\
\hline EDTA & - & $98.16 \pm 2.78^{b}$ & - & - & - & - \\
\hline Acarbose & - & - & $80.41 \pm 2.36^{d}$ & $93.21 \pm 3.12^{c}$ & $95.34 \pm 1.54^{c}$ & $97.08 \pm 1.67^{c}$ \\
\hline
\end{tabular}

The final concentrations tested were $50 \mu \mathrm{g} / \mathrm{ml}$ for chelating activity, $100 \mu \mathrm{g} / \mathrm{ml}$ for a-amylase inhibition and 25,50 and $100 \mu \mathrm{g} / \mathrm{ml}$ for a-glucosidase inhibition. F1 to F9 from F. apodanthera and 01 to 010 from $O$. insignis are fractions obtained by column chromatography. Values with superscript letters, $a, b, c$, d, e differ significantly $(p<0.05)$. NA= No Activity $(\leq 1 \%)$, - not tested

inhibition of $\alpha$-glucosidase except the F1, F2, F3, F6, $\mathrm{O} 1, \mathrm{O} 3$ and $\mathrm{O} 8$ fractions that displayed weak activity. Correlative analysis showed that the chelating power was inversely correlated with the inhibitions of $\alpha$-amylase $(\mathrm{R}=-0,731)$ and $\alpha$-glucosidase $(\mathrm{R}=-0,809)$. A direct correlation between $\alpha$-amylase and $\alpha$-glucosidase inhibition was also established $(\mathrm{R}=0.389)$ but that was not significant.

The most active fractions F4, F5 and O7 were analyzed by GC-MS and 13 volatile compounds were identified (Table 3), including silicates (tetramethyl silicate and silane, ethyltrimethoxy-), hydrocarbons (1-nonadecene, 1-heptadecene) and benzene derivatives (1,2-benzenediol, 1,2-benzenedicarboxylic acid, diisooctyl ester).

Controlling glucose level in the body plasma is a key challenge for maintaining glucose homeostasis and make balance between the need in glucose as source of energy for the body and its accurate metabolism to avoid glucose overdose. In case of diabetes, the glucose homeostasis is hampered leading to high glucose level in the plasma. To avoid this hyperglycaemia, reducing glucose absorption is a key solution and inhibition of $\alpha$-amylase and $\alpha$-glucosidase is very meaningful.
Among the seven plant species tested for $\alpha$-amylase inhibition, only $F$. apodanthera and $O$. insignis exhibited significant inhibition as compared to the standard acarbose at the same final concentration of $100 \mu \mathrm{g} / \mathrm{ml}$ in the test solution. The aqueousacetone extract of $O$. insignis with the most important $\alpha$-amylase inhibition percentage was dose-dependently tested and raised an $\mathrm{IC}_{50}$ value of $22.04 \pm 1.27 \mu \mathrm{g} / \mathrm{ml}$. This activity is significant as compared to other plant species where among 126 extracts, the most active were Linum usitatisumum ( $\mathrm{IC}_{50} 540 \mu \mathrm{g} / \mathrm{ml}$ ), leaves of Morus alba $\left(\mathrm{IC}_{50} 1440 \mu \mathrm{g} / \mathrm{ml}\right)$ and Ocimum tenuiflorum $\left(\mathrm{IC}_{50} 8.9 \mu \mathrm{g} / \mathrm{ml}\right)^{[8]}$.

Essential oil components have been reported as good inhibitors of $\alpha$-amylase ${ }^{[15]}$ and the volatile compounds, 1-nonadecene and 1-heptadecene might contribute to the observed activity of the aqueous-acetone extract of $O$. insignis. This extract simultaneously displayed marked inhibition on $\alpha$-glucosidase, together with $F$. apodanthera and F. agrestis. Therefore, no significant correlation was found between the inhibitions of the two enzymes $(\mathrm{R}=0,389)$. Thus, an extract did not necessarily display concomitant strong or weak inhibitions of both glycosidases as previously noticed ${ }^{[16]}$. This is dependent on the structure of each 
TABLE 3: COMPOUNDS IDENTIFIED BY GC-MS FROM FRACTIONS F4, F5 AND O7 OF F. APODANTHERA AND O. INSIGNIS

\begin{tabular}{lccccc}
\hline No & RT $(\mathrm{min})$ & Name & F4 & F5 & O7 \\
\hline & & & Area (\%) \\
1 & 2.53 & Silane, ethyltrimethoxy- & - & 1.43 & - \\
2 & 3.98 & Tetramethyl silicate & 9.66 & 25.54 & - \\
3 & 11.83 & Decane $<$ n-> & 0.88 & 4.65 & 24.31 \\
4 & 14.93 & Pyrolo[3,2-d] pyrimidin-2,4(1H,3H)-dione & 0.27 & 2.70 & - \\
5 & 15.31 & Undecane $<$ n-> & 0.47 & 2.68 & 10.57 \\
6 & 19.71 & 1,2 -Benzenediol & - & - & 24.14 \\
7 & 19.95 & $1,2,4-$ Triazolo[4,3-b] pyridazine & - & - & 6.45 \\
8 & 20.23 & 1,2-Bis(3,5-dimethylphenyl)-diazene 1-oxide & - & 1.24 & - \\
9 & 26.08 & o-Hydroxyacetophenonylidene-4,5-dimethyl-0-phenylenediamine & 7.64 & 40.53 & - \\
10 & 33.55 & 1-Nonadecene & - & - & 8.35 \\
11 & 37.61 & 1-Heptadecene & - & - & 9.06 \\
12 & 39.41 & 1,2-Benzenedicarboxylic acid, diisooctyl ester & 81.08 & - & - \\
13 & 43.97 & Acetic acid, [(2,4,6-triethylbenzoyl) thio]- & - & 12.77 & - \\
\hline
\end{tabular}

‘-' Means not identified

enzyme, the nature of the inhibitor and the mechanism of the inhibition. Scoparia dulcis was mentioned to possess strong antidiabetic activity in vivo by reducing blood glucose and increasing the plasma insulin in streptozotocin diabetic rats ${ }^{[12,17]}$; but in the present in vitro study it did not display any inhibitory activity on both $\alpha$-amylase and $\alpha$-glucosidase, suggesting that different mechanism of antihyperglycemic action may occurs after glucose absorption.

Indirect and significant correlation has been established between the chelating activity of the plant species and their inhibition on $\alpha$-amylase and $\alpha$-glucosidase suggesting that different compounds in the plant extracts and fractions may be engaged in the reactions along the chelating assay and the enzymes inhibition.

Accordingly, the aqueous-acetone extracts of $F$. apodanthera and $O$. insignis displayed significant inhibitions on $\alpha$-amylase and $\alpha$-glucosidase but no metal chelating activity; in opposite, the other extracts (S. pyramidalis, S. dulcis, L. anobrya and water extract of $E$. balsamifera) showed moderate chelating power but no inhibition on $\alpha$-amylase and $\alpha$-glucosidase except $F$. agrestis and aqueous-acetone extract of E. balsamifera that exert action on both metal chelation and glycosidases inhibition (fig. 1).

However, some authors established direct correlation between antioxidant activity based on DPPH assay and the inhibitions of $\alpha$-amylase and $\alpha$-glucosidase ${ }^{[18-20]}$. This different observation with the present study can be related to the difference between DPPH assay and chelating activity. DPPH assay is a primary antioxidant system in which the antioxidant directly reacts with the radical, while chelating activity is a secondary antioxidant model where the chelation of iron (II) ion by the antioxidant will prevent the initiation of oxidative process and hydroxyl radical production through the Fenton reaction. Previous studies also correlated the total phenolic content and the inhibitions of $\alpha$-amylase and $\alpha$-glucosidase ${ }^{[19,21]}$ so that the polyphenols contained in the present targeted plant species may be strongly implicated in the two enzymes inhibitions. Hence, $F$. apodanthera and $O$. insignis that exhibited great glycosidase inhibition in this study also displayed highest polyphenols content in our previous work $^{[22]}$. Therefore, enzyme inhibition by the plant samples is not only dependent on their content in polyphenols but may also include the structure-activity relationship that is mainly involved in the chelating activity. For indeed, the metal chelating ability of polyphenols was found to be related to the presence of an o-dihydroxyl moiety in their chemical structures or those bearing catechol or galloyl groups ${ }^{[23]}$. This can moreover justify why glycosidase inhibition was found to be correlated with polyphenols content ${ }^{[17,19,21]}$ but not with chelating activity, since no correlation was found between chelating activity and polyphenol content ${ }^{[24,25]}$. Phenolic glycosides are unable to bind metals ${ }^{[26]}$ so that the chelating activity of the different plant extracts may be related to the glycosylation of their phenolic compounds as it occurs in natural plants; the phenolic compounds in the plant extracts with great chelating activity may be less glycosylated. And accordingly, the phenolic compounds in the aqueous-acetone extracts of $F$ apodanthera and $O$ insignis that did not get any chelating activity may be mostly phenolic glycosides. Consecutively, the availability of carbohydrates due to the glycosylation of phenolic compounds present 
Biplot (axes F1 et F2 : 100,00\%)

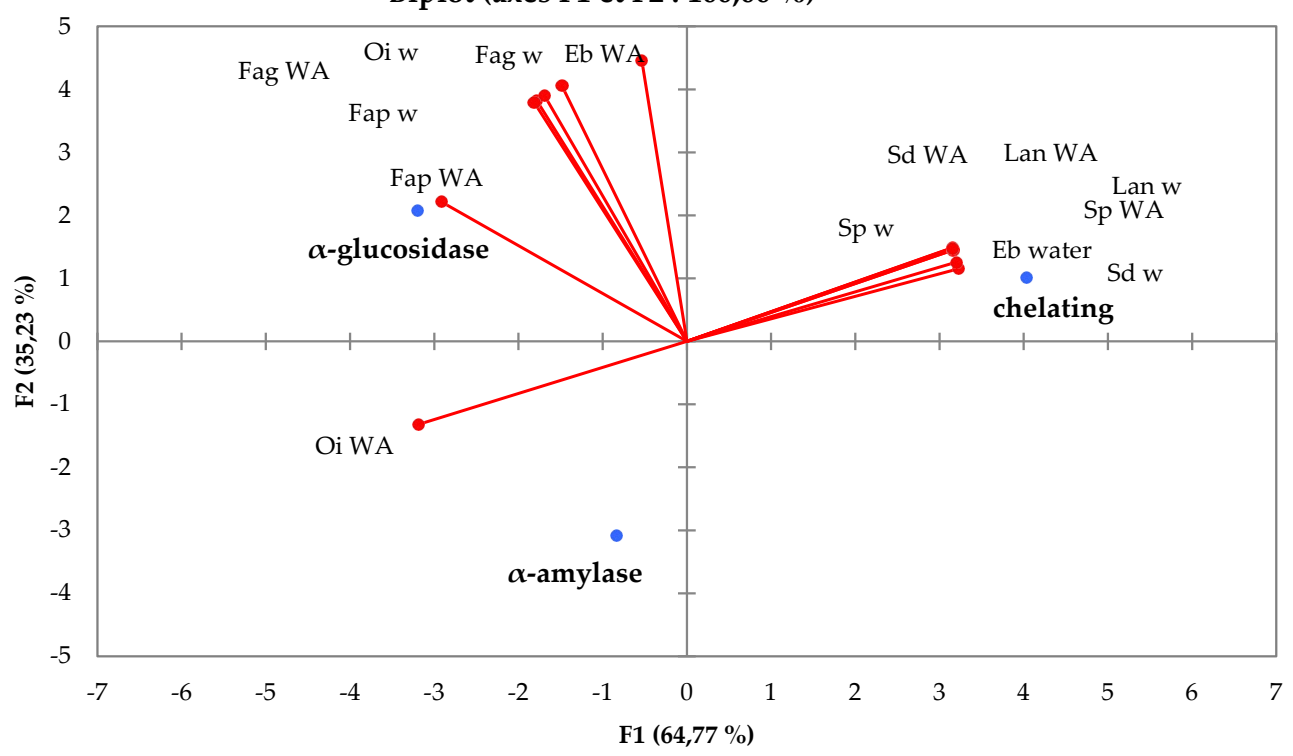

Fig. 1: Principal component analysis of metal chelation and glycosidases inhibition WA is water-acetone, w= water, Eb, Euphorbia balsamifera; Fag, Fadogia agrestis; Fap, Feretia apodanthera; Lan, Lepidagathis anobrya; Oi, O. insignis and Sp, Sporobolus pyramidalis

in these two plant extracts may also involve in their great inhibition of $\alpha$-glucosidase, since the type of $\alpha$-glucosidase inhibitor drugs available today, such as acarbose and miglitol are carbohydrate compounds.

Many studies demonstrated that metals are required for the induction of glucose-induced ROS production ${ }^{[3,4,27]}$. Glucose radicals can react with metals and hydrogen peroxide to create hydroxyl radical, the most reactive ROS. This mechanism may be especially important in cells lacking mitochondria, such as erythrocytes.

The aqueous-acetone extract of $F$. agrestis showed greater activity both on metal chelation and $\alpha$-glucosidase inhibition while $O$. insignis appeared to be suitable for inhibiting both glycosidases. Overall, fraction $\mathrm{O} 7$ is likely the best candidate to investigate further to identify constituents with both metal chelation ability and glycosidase inhibition potential. Targeted plant samples with chelating activity that can prevent glucose oxidation and ROS generation along with antiglycosidase effects might help to manage hyperglycemia and diabetes better.

\section{Acknowledgements:}

Authors thank Prof. Jeanne F. Millogo, Laboratoire de Biologie et Ecologie Vegetales, University of Ouagadougou for identifying the plants used in this investigation. This research was funded by The World Academy of Sciences (TWAS) and Universiti Sains Malaysia (USM) under postdoctoral fellowship [number: 3240255139].

\section{Conflicts of interest:}

The authors declare no conflict of interest.

\section{REFERENCES}

1. Llanos P, Contreras-Ferrat A, Barrientos G, Valencia M, Mears D, Hidalgo C. Glucose-dependent insulin secretion in pancreatic $\beta$-cell islets from male rats requires $\mathrm{Ca} 2+$ release via ros-stimulated ryanodine receptors. Plos One 2015;10 (6):e0129238.

2. Kim SH, Park MJ. Effects of growth hormone on glucose metabolism and insulin resistance in human. Ann Pediatr Endocrinol Metab 2017;22 (3):145-152.

3. Kanti Das T, Wati MR, Fatima-Shad K. Oxidative stress gated by Fenton and Haber Weiss reactions and its association with Alzheimer's disease. Arch Neurosci 2014;2 (3):e20078.

4. Prousek J. Fenton chemistry in biology and medicine. Pure Appl Chem 2007;79 (12):2325-2338.

5. Verberne AJM, Sabetghadam A, Korim WS. Neural pathways that control the glucose counterregulatory response. Front Neurosci 2014;8:38.

6. Dayananda KS, Gopinath SM. Antidiabetic effect of a poly herbal formulation (D) on human pancreatic amylase. Int $\mathrm{J}$ Pharm Bio Sci 2013;4 (4):460-466.

7. Leena AA, Jill PC. Type 2 diabetes prevention: A review. Clin Diab 2010;28(2):53-59.

8. Sudha P, Zinjarde SS, Bhargava SY, Kumar AR. Potent $\alpha$-amylase inhibitory activity of Indian Ayurvedic medicinal plants. BMC Complement Altern Med 2011;11:5.

9. Tarling CA, Woods K, Zhang R, Brastianos HC, Brayer GD, Andersen RJ, et al. The search for novel human pancreatic $\alpha$-amylase inhibitors: high-throughput screening of terrestrial and marine natural product extracts. ChemBioChem 2008;9(3):433-8.

10. Cheng AYY. Oral antihyperglycemic therapy for type 2 diabetes mellitus. Canadian Med Assoc J 2005;172(2):213-26. 
11. Mukherjee PK, Maiti K, Mukherjee K, Houghton PJ. Leads from Indian medicinal plants with hypoglycemic potentials. J Ethnopharmacol 2006;106 (1):1-28.

12. Pari L, Latha M. Antidiabetic effect of Scoparia dulcis: effect on lipid peroxidation in streptozotocin diabetes. Gen Physiol Biophys 2005, 24:13-26.

13. Rau O, Wurglics M, Dingermann T, Abdel-Tawab M, SchubertZsilavecz M. Screening of herbal extracts for activation of the human peroxisome proliferator-activated receptor. Pharmazie 2006;61(11):952-56.

14. Ooi KL, Muhammad TST, Tan ML, Sulaiman SF. Cytotoxic, apoptotic and anti- $\alpha$-glucosidase activities of 3,4-di-O-caffeoyl quinic acid, an antioxidant isolated from the polyphenolicrich extract of Elephantopus mollis Kunth. J Ethnopharmacol 2011;135(3):685-95.

15. Loizzo MR, Saab AM, Statti GA, Menichini F. Composition and $\alpha$-amylase inhibitory effect of essential oils from Cedrus libani. Fitoterapia 2007;78(4):323-326.

16. Wongsa $\mathrm{P}$, Chaiwarit J, Zamaludien A. In vitro screening of phenolic compounds, potential inhibition against $\alpha$-amylase and $\alpha$-glucosidase of culinary herbs in Thailand. Food Chem 2012;131(3):964-71.

17. Pari L, Latha M. Protective role of Scoparia dulcis plant extract on brain antioxidant status and lipidperoxidation in STZ diabetic male Wistar rats. BMC Complement Altern Med 2004;4:16.

18. Pinto DSM, Kwon Y-I, Apostolidis E, Lajolo FM, Genovese MI, Shetty K. Potential of Ginkgo biloba L. leaves in the management of hyperglycemia and hypertension using in vitro models. Bioresource Technol 2009;100(24):6599-609.

19. Lee SY, Mediani A, Nur Ashikin AH, Azliana ABS, Abas F. Antioxidant and $\alpha$-glucosidase inhibitory activities of the leaf and stem of selected traditional medicinal plants. Int Food Res J 2014;21 (1):165-172.

20. Manaharan T, Palanisamy UD, Ming $\mathrm{CH}$. Tropical plant extracts as potential antihyperglycemic agents. Molecules 2012;17(5):5915-23.

21. Mai TT, Thu NN, Tien PG, Chuyen NV. Alpha-glucosidase inhibitory and antioxidant activities of vietnamese edible plants and their relationships with polyphenol contents. J Nutr Sci Vitaminol 2007;53(3):267-76.

22. Coulibaly AY, Hashim R, Sulaiman SF, Sulaiman O, Ang LZP, Ooi KL. Bioprospecting medicinal plants for antioxidant components. Asian Pac J Trop Med 2014;7:S553-S559.

23. Andjelkovic M, Vancamp J, Demeulenaer B, Depaemelaere $\mathrm{G}$, Socaciu C, Verloo M, et al. Iron-chelation properties of phenolic acids bearing catechol and galloyl groups. Food Chem 2006;98(1):23-31.

24. Ebrahimzadeh MA, Pourmorad F, Bekhradnia AR. Iron chelating activity, phenol and flavonoid content of some medicinal plants from Iran. Afr J Biotechnol 2008;7(18):318892.

25. Sulaiman SF, Ooi KL, Supriatno. Antioxidant and $\alpha$-glucosidase inhibitory activities of cucurbit fruit vegetables and identification of active and major constituents from phenolic-rich extracts of Lagenaria siceraria and sechium edule. J Agric Food Chem 2013;61(42):10080-90.

26. Tungmunnithum D, Thongboonyou A, Pholboon A, Yangsabai A. Flavonoids and other phenolic compounds from medicinal plants for pharmaceutical and medical aspects: An Overview. Medicines 2018;5(3):93.

27. Luo J, Xiang Y, Xu X, Fang D, Li D, Ni F, et al. High glucoseinduced ros production stimulates proliferation of pancreatic cancer via inactivating the jnk pathway. Oxid Med Cell Longev $2018 ; 1: 10$. 